\title{
THE RULE OF LAW IN INDIAN ADMINISTRATIVE LAW VERSUS THE PRINCIPLE OF LEGALITY IN SOUTH AFRICAN ADMINISTRATIVE LAW: SOME OBSERVATIONS
}

\author{
Radley Henrico \\ BProc LLB LLM LLD \\ Associate Professor, Department of Public Law \\ and Jurisprudence \\ University of the Western Cape \\ Advocate of the High Court of South Africa
}

\section{SUMMARY}

The rule of law is expressly mentioned in the Constitution of the Republic of South Africa, 1996. The principle of legality has flourished in South African administrative law since its recognition and reception into our law in Fedsure Life Assurance Ltd $v$ Greater Johannesburg Transitional Metropolitan Council 1999 (1) SA 374 (CC). The Indian Constitution does not contain an equivalent expression of the rule of law. Notably, how persons and societies in India govern themselves is premised upon beliefs akin to the rule of law. Moreover, Indian administrative law has been strongly influenced by the theory of the rule of law as advocated by Dicey. Whilst Indian administrative law relies heavily upon the rule of law to judicially review conduct that is capricious, South African administrative law has come to rely on the incident of the rule of law, namely the principle of legality. This contribution inspects some of the reasons why the rule of law is heavily relied on in Indian administrative law - where it essentially mirrors the South African administrative law principle of legality. This contribution also suggests reasons as to why the principle of legality is so prevalent in South African administrative law as opposed to merely the rule of law as employed by the Indian courts in Indian administrative law.

\section{INTRODUCTION}

A founding value of the Constitution of the Republic of South Africa ${ }^{1}$ (the Constitution) is that of a democratic system of government ensuring accountability, responsiveness, and openness. ${ }^{2}$ The principle of legality is an incident of the rule of law and is often regarded as a "catch-all" mechanism, and in South African administrative law it serves as a useful means to hold

1996.

S $1(d)$. 
accountable the exercise of all public (and private) power by increasing the scope of judicial review. The rule of law is another founding value of the Constitution. ${ }^{3}$ The Constitutional Court in Fedsure Life Assurance Ltd v Greater Johannesburg Transitional Metropolitan Council 1999 (1) SA 374 (CC) recognised the significance of the legality principle as an implicit means of calibrating the validity of the exercise of public power, but subject to the following caveat:

"[t]he principle of legality is implied within the terms of the interim Constitution. Whether the principle of the rule of law has greater content than the principle of legality is not necessary for us to decide here. We need merely hold that fundamental to the interim Constitution is a principle of legality." 4

Section 1(c) of the Bill of Rights expressly recognises the supremacy of the Constitution and the rule of law. The effectiveness of the Bill of Rights is galvanised by virtue of its application to all law and it binds the legislature, the executive, the judiciary, and all organs of state. ${ }^{5}$ To date, there has been no definitive judgment (as far as the author is aware) on whether the rule of law indeed has greater content than the principle of legality. However, numerous applications for judicial review of administrative action and nonadministrative action often succeed on the basis that the exercise of power in question is contrary to the principle of legality. Sripati compellingly asserts that the historic links between South Africa and India are captured by Mahatma Gandhi who stated: "The freedom of India started in South Africa; and [India's] freedom will not be complete till South Africa is free". ${ }^{6}$

This contribution inspects the historical links between India and South Africa to establish a rationale to examine a specific aspect of administrative law between the two countries, namely the reliance on the rule of law in administrative law. A treatise would be required to comment on the full gamut of administrative law. Instead, this contribution aims to examine why the principle of legality is employed so effectively in South African administrative law as opposed to merely the rule of law as employed in Indian administrative law. In examining the above, reasons are proffered for this apparent anomaly.

\section{THE NEXUS BETWEEN INDIA AND SOUTH AFRICA}

The abolition of slavery on 28 August 1833 in the British Empire ${ }^{7}$ was bittersweet. It meant emancipation for some but not for Indians. During the 1860s, large-scale shipments of Indians to British colonies to work on sugar plantations translated into some 1.2 million Indian labourers to South Africa;

S 1(c).

$4 \quad$ Fedsure Life Assurance Ltd v Greater Johannesburg Transitional Metropolitan Council 1999 (1) SA 374 (CC) 57. Author's own emphasis.

5 S 8(1).

6 Sripati "Constitutionalism in India and South Africa: A Comparative Study from a Human Rights Perspective” 200716 Tulane Journal of International and Comparative Law 4952. esp. the authorities cited at fn 1.

7 In terms of the Slavery Abolition Act, 1833. 
particularly the sugar plantations in Natal. ${ }^{8}$ This form of labour used by the British Empire in its sugarcane colonies proved vital to sustain the sugar industry in Britain. As observed by the pejorative remark of the Royal Commission of Labour in 1892, "importation of East Indian Coolies did much to rescue the sugar industry from bankruptcy". ${ }^{9}$ The system of indentured labour would prove to last from 1860 to approximately 1914. This system was resisted by many Indians forced to work in appalling conditions, and Gandhi, in particular, advocated the philosophy of Satyagraha ${ }^{10}$ as a means of resisting the racial discrimination that characterised such a system of forced labour. ${ }^{11}$ At the end of the indentured (forced) labour in 1911, approximately 1,5 million Indians arrived in Natal. Statistics captured in 1996 revealed that approximately 2,6 per cent of the total population of approximately 40.5 million were descendants of the aforesaid indentured labourers as well as those Indians who had voluntarily travelled to South Africa to seek out a better life for themselves. ${ }^{12}$

South Africa and India are both diverse ethno-pluralistic secular ${ }^{13}$ societies. In 2018, Pew Research Centre calculated that India, at that time, had a population of 1,4 billion people and home to 94 per cent of the world's Hindus with substantial Muslim, Christians, Sikhs, Buddhists, Jains, and "adherents of folk religions". ${ }^{14}$ In 2015 , statistics in South Africa ${ }^{15}$ revealed that 86 per cent of the population regarded themselves as Christians; 5,4 per cent Ancestral Tribal, Animist, or other African religion; 5,2 per cent nothing

8 Sen "Indentured Labour from India in the Age of the Empire" 201635 Social Scientist 35 38; Sturman "Indian Indentured Labour and the History of International Rights Regimes" 20145 American Historical Review 14391441.

9 Sen 2016 Social Scientist 43.

10 Civil disobedience. See Ramaswany "Gandi's Satyagraha in South Africa and the Tamils" 201039 Economic and Political Weekly 36 38; Czekalska and Klosowicz "Satyagraha and South Africa: Part 1: The Origins and the Relationship Between the Idea and the Place in Mahatma Gandhi's Writings" 201640 Politeja 31 34-36 esp. the authorities cited at fn 1, $6-7,9$ and 12

11 Pachauri "The Indentured Labour System and the Roots of Indian Policy Toward South Africa" 199758 Proceedings of the Indian History Congress 732733.

12 Prabhakara "India and South Africa: Cautionary and Salutary Lessons" 200338 Economic and Political Weekly 1839 1840. Significantly this figure has reduced to 1,5 million of the 58,78 million population figure as per mid-year population estimates conducted by the government in 2019, see "Mid-Year Population Estimates 2019" (2019) http://www.statssa.gov.za/publications/P0302/MYPE\%202019\%20

Presentation_final_for\%20SG\%2026_07\%20static\%20Pop_1.pdf (accessed 2020-09-09).

13 In the sense that a society is representative of people from diverse cultural, ethnic, racial, and religious backgrounds without the state supporting any particular religion, see Coertzen "Religion and the Common Good in a Pluralistic Society - Reformed Theological Perspectives" 201253 Supplementum 175 178; Botha "Human Dignity in Comparative Perspective" 200920 Stell LR 171 193-194, 204-210 and 214-215; Das Acevedo "Secularism in the Indian Context" 201338 Law \& Social Inquiry 138 140ff; Chisti "Secularism in India: An Overview" 200465 The Indian Journal of Political Science 183 185-188. Significantly, in Kesavananda Bharati v State of Kerala (1973) 4 SCC 225, the constitutional bench of the Supreme Court of India emphasised the secularism aspect of the Indian Constitution.

14 Majumdar "Five Facts About Religion in India" (29 June 2018) https://www.pewresearch.org/fact-tank/2018/06/29/5-facts-about-religion-in-india/ (accessed 2020-09-09).

15 See "General House Survey" (2015) http://www.statssa.gov.za/publications/P0318/ P03182015.pdf (accessed 2020-09-09) 27-28. 
in particular; 1,9 per cent Muslim; 0,9 per cent Hindu; and 0,2 per cent Jewish. ${ }^{16}$ The Preamble of the Constitution of India ${ }^{17}$ unapologetically states that India is a secular state. Article 15(1) of the Indian Constitution expressly provides that the state shall not discriminate against any citizen on grounds of, inter alia, religion. Such proscription against state interference in the affairs of religion is also evident in sections 15(1) and 31(1)-(2), as read with section 9(3) of the Constitution.

When India gained independence from Britain ${ }^{18}$ it maintained its independence as a dominion within the British Commonwealth. ${ }^{19}$ South Africa's departure from the commonwealth ${ }^{20}$ endured until it became a democracy in 1994. ${ }^{21}$ As member states of the Commonwealth, India and South Africa also share significant international economic and political cooperation as two of the BRICS countries. ${ }^{22}$

Finally, a relationship of reciprocity exists between our Constitutional Court - in the interpretation of the Bill of Rights - and the Indian Supreme Court to the extent that each draws on the jurisprudence of the other. ${ }^{23}$ The common heritage shared between India and South Africa establishes a basis to discuss the different approaches to the application of the principle of legality and the rule of law.

\section{THE RULE OF LAW IN INDIA}

The Constitution of India ${ }^{24}$ (the Indian Constitution) contains fundamental rights as set out in part III. ${ }^{25}$ Part III of the Indian Constitution sets out the fundamental rights. As suggested in the rubric "fundamental rights", specific articles govern the constitutional guarantee of, for example, equality before

16 Additional religious affiliations are indicated as: other religion, nothing in particular or do not know.

17 Dated 26 January 1950, see Brigg and Uddin "Government of India, Ministry of Law and Justice, Legislative Department" (2019) http://legislative.gov.in/sites/default/files/COIupdated.pdf (accessed 2020-09-10)

18 On 14 August 1947.

19 Kreling "India and the Commonwealth: A Symbiotic Relationship?" 200998 The Round Table 4950

20 On 31 May 1961. For further reading see Miller "South Africa's Departure" 19611 Journal of Commonwealth Political Studies 56 58-63.

21 Shaw and Ashworth Commonwealth Perspectives of International Relations (2010) 210.

22 Anuoluwapo "Gandhi's 'Hind Swaraj' - Swarajya, the Swadeshi Way" 201964 The Indian Journal of Political Science 2529.

23 In accordance with $s$ 39(1)(b)-(c) of the Constitution. See Lollini "The South African Constitutional Court Experience: Reasoning Patters Based on Foreign Law" 20128 Utrecht Law Review 55 66-67 esp. the authorities cited at fn 50 and 51; S v Makwanyana 1995 (3) SA 391 (CC) 16; S v Dodo 2001 (3) SA 382 (CC) 32; S v Mamalobo 2001 (3) SA 409 (CC) 49 fn 48; Pillay "Protecting Judicial Independence Through Appointments Processes: A Review of the Indian and South African Experiences" 20183 Indian Law Review 283-311; Bentele "Mining For Gold: The Constitutional Court of South Africa's Experience With Comparative Constitutional Law" 200937 Georgia Journal of International and Comparative Law 219248.

24 Adopted by the Indian Constituent Assembly 26 November 1949, coming into effect on 26 January 1950.

25 Articles 12-35. 
the law. ${ }^{26}$ Express provision is made for fundamental rights such as freedom of religion, race, caste, sex, or place of birth; ${ }^{27}$ equality in matters of public employment; ${ }^{28}$ and the right to freedom of expression. ${ }^{29}$ None of the aforesaid articles, nor any other substantive provision of the Indian Constitution specifically expressly refer to the rule of law. It may be argued that the rule of law is anticipated with reference to the Preamble, which provides, among other things, that India secures "to all its citizens justice".

It is no surprise that justice is expressly mentioned. Gandhi advocated the necessity for a "just society" as essential for India's future and survival. ${ }^{30}$ The concept of Ram Rajya and Swarajya was central to Gandhi's views. The former concept was first articulated by Valmiki Ramayana in Hindu epic literature in the $2^{\text {nd }}$ century. ${ }^{31}$ It is one which may be considered Utopian in its vision in the concept of an idealised society in which all people were endowed with virtues and lived in harmony with all other living creatures, trees, and plants without inflicting any form of harm on the latter. Gandhi interpreted this ancient vision as applying to a democratic society in which "the land of Dharma ${ }^{32}$ and a realm of peace, harmony and happiness for young and old, high and low, all creatures and the earth itself, in recognition of a shared universal consciousness". ${ }^{33}$ Applied to a more contemporary civil-political setting it aims to conceive of a society in which justice, peace, and prosperity prevail. ${ }^{34}$ The latter concept (which is also Vedic related) pertains to the concept of self-governance or self-rulership. In particular, it was argued by Gandhi that the imperative of "self-rule" translating into a selfimposed rule of one's own emotions, namely discipline from within, is central to the independence of India. ${ }^{35}$ Axiomatic to Indian independence (under the dictates of Swarajya) was a government that that was neither oppressive nor tyrannical but in which the rule of justice prevailed for all people in a democratic dispensation. ${ }^{36}$

Article 14.

Articles 15(1)-(5)

Articles 16(1)-(3).

Articles 19(1)(a)-(e).

Sarda and Akhtar "Concept of Dharma, Justice and the Law: A Study" 20171 Bharati Law Review 179179 esp. authority cited at fn 8.

31 The $2^{\text {nd }}$ century refers to the period from 1 January $199 \mathrm{BC}$ to 31 December $100 \mathrm{BC}$ https://www.trismegistos.org/time/detail.php?period_id=48945_85469\&strict=2\#geodetailable (accessed 2021-11-30) which forms part of the Classical era, see De Meister Introducing Philosophy of Religion (2009) 10.

32 Hinduism can be considered as an indigenous religion of India that takes into account the Vedas (a large body of religious texts from ancient India composed in Vedic Sanskrit - the oldest scriptures of Hinduism - in terms of which dharma may be interpreted as right and proper moral conduct in respect of one's own acts and toward the human community. See Hacker "Dharma in Hinduism" 200634 Journal of Indian Philosophy 479 480; Balakrishnan and Hamid "Valmiki Ramayana: A Spiritual Hermeneutic Meaning" 201810 International Journal of Academic Research in Business and Social Sciences 12351236.

33 Modh "International Humanitarian Law: An Ancient Indian Perspective" (2011) 12 esp the authority cited at ftn $5 \mathrm{http} / / / \mathrm{dx}$.doi.org/10.2139/ssrn.1738806 (accessed 2021-11-30).

34 lbid.

35 Anjaneyulu “Gandhi's 'Hind Swaraj' - Swarajya, the Swadeshi Way” 200364 The Indian Journal of Political Science 2536.

36 Ghandi Young India (1928) 774. 
Regarding the "land of Dharma", it is significant to note that Dharma itself has been identified as a Sanskrit noun akin to the Greek term "ethos Max Muller makes a compelling argument to define dharma as an Indian version of natural law since people of ancient times used dharma as "a way of life, to regulate their behaviour and govern themselves". ${ }^{37}$ Notably, the classical law of India is characterised by the moral authority and duty imposed by Dharma, which emphasises eternal rules necessary to maintain oneself and the entire world, as opposed to the restraining power of legality in Western traditions. Lingat correctly refers to the fact that rules in classical India were perceived to be of divine origin. ${ }^{38}$ From a Vedic view, the order required in the life of an individual was a micro-version of the order necessary for order in the public realm. This came to inform the important concept in classical Indian traditions that all members of society, including the King, were subordinate to the Priest (the Brahman). Hence, temporal power is subordinate to spiritual power. By subordinating himself to this spiritual power even the King (head of the executive) was subject to a greater power. Law in classical India came to consist of the sacred texts (Manu Smriti) and custom or unwritten laws (classical Indian law). Considering the fact that custom often contradicted the sacred texts, the relationship between the two was regarded as complex and at times contradictory. These doctrines, which may be perceived as being of a spiritual nature, took on meanings that transcended the religious or spiritual realm and came to inform the sociolegal structure of society by imposing obligations on how a person was required to conduct themselves and behave in relation to other persons. Dharma thus prescribed a moral code to be followed individually and universally. Since ancient times, ${ }^{39}$ dharma was thus regarded as the only source of law, referred to as the Dharmashastras. ${ }^{40}$ The significance of the latter is that it formed a part of the Civil Code of Conduct in India under colonial British rulership. ${ }^{41}$

A seismic shift in Indian law took place under British colonial rulership commencing with the East India Company in the $18^{\text {th }}$ century. The latter sought to impose a uniform judicial and administrative system. An abiding concern was to impose British law ${ }^{42}$ while preserving classical law. This was a challenging process compounded by the fact that, at the time of colonialism, parts of India were subject to British rulership while other parts fell within the remit of various Indian Princes. Warren Hastings, ${ }^{43}$ continued

Rocher "Hindu Conceptions of the Rule of Law" 197829 Hastings Law Journal 12831291.

38 Linglat The Classical Law of India (translated from the French with additions by Derrett) (1973) 305.

39 Medieval era is described as the time referring to the fall of the Western Roman empire in the $5^{\text {th }}$ century AD continuing to the signing of the Magna Carta in 1215; see Amarasinghe "Evaluating the Concept of Dharma in Medieval Hindu Legal Traditions with Thomas Aquinas' Natural Law Philosophy" (LLM mini-dissertation, South Asian University, New Delhi) 201732 and especially the authority cited at fn 32 .

40 Or Dharmasutras.

41 Rajpal and Vats "Dharma and the Indian Constitution" 20165 Christ University Law Journal 57 65. British domination (colonialisation of India) took place circa 1858 to 15 August 1947, see Ahanchi "Reflections of the Indian Independence in the Iranian Press" 200942 Iranian Studies 423424.

42 Consisting of written rules pertaining to private and public law.

43 Appointed as Governor-General in 1772. 
this tradition (acknowledging classical law) as did subsequent GovernorGenerals. ${ }^{44}$ They saw it as their charge to attempt to preserve and incorporate as much of classical Indian law into the imposed English law. ${ }^{45}$ The rationale therefor was to establish a constructive relationship between British domination and the people of India. In furtherance of colonialism, the aforesaid view of classical Indian law was opposed by subsequent British Governor-Generals. ${ }^{46}$

Although the Dharmashastras were considered during British colonial rule, it is interesting to note that when the Constituent Assembly debated the formation of a Constitution, ${ }^{47}$ no efforts were made to include Dharmashastras in the Constitution. Instead, the Indian Constitution would provide an alternative to the Dharmashastras. Whilst the rule of law is not expressly stated in the text of the Constitution itself, the Constitution is recognised as being based on the rule of law, consonant with the realisation of a democratic society. Moreover, the drafters of the Constitution were also familiar with the rule of law concept as postulated by Albert Vinn Dicey. ${ }^{48}$ Dicey's theories ${ }^{49}$ are all-pervasive in the Indian Constitution. ${ }^{50}$

It is through judicial activism that the rule of law has survived from ancient times to modern-day India. In addition, it has been conceptually expanded for purposes of protecting the rights of citizens and supervising the extent to which the other two arms of government act within the powers conferred upon them. ${ }^{51}$ Judgments of the Supreme Court of India affirm the extent to which the rule of law is recognised as an inexorable part of constitutionalism. In Golaknath v State of Punjab ${ }^{52}$ the Court held that parliament could not curtail any of the fundamental rights contained in the Constitution and stated

"[r]ule of laws under the Constitution has the glorious content. It embodies the concept of law involved over the centuries." 53

44 Such as Henry Munro. For further reading in this regard see Peers "Colonial Knowledge and the Military in India, 1780-1860" 20053 The Journal of Imperial and Commonwealth History 159.

45 For further reading on India under British colonialism see Wiener "The Idea of "Colonial Legacy' and the Historiography of Empire" 20133 Journal of the Historical Society 25.

46 Namely Cornwallis, Governor-General from 1793.

47 From 1947-1949.

48 In his work: Dicey The Law of the Constitution (1885).

49 Namely, absence of discretionary power supremacy of the law; equality before the law; and protection of the rights of citizens through the administration of justice.

50 The framing of the Indian Constitution, which took a period of three years, from 1947-1949 falls outside the focus of this article. For reading in this regard, see Raju "Dr B.R. Ambedkar and the Making of the Constitution: A Case Study of Indian Federalism" 199152 The Indian Journal of Political Science 153-164; Murthy and Mahin "Constitutional Impediments to Decentralization of the World's Largest Federal Country" 201526 Duke Journal of Comparative and International Law 79-138.

51 For general reading on judicial activism in the sense of the courts' having the power to determine and pronounce what the law is by protecting liberty of all persons against the exercise of arbitrary or irrational power, see Tripathi "Rule of Law, Democracy, and the Frontiers of Judicial Activism" 197517 Journal of the Indian Law Institute 17-36; Singhania "Judicial Activism in India" 20184 International Journal of Law 238-242; Rishi and Ananth "Judicial Activism in India: Whether More Populist or Less Legal?" 20171 Indian Journal of Constitutional and Administrative Law 11-23.

52 (1967) 2 SCR 276.

53 Par 98. 
This judgment recognises the rule of law as it has evolved over the centuries and makes clear that a derivative of the rule of law in the realm of administrative law is the judicial review of administrative action to ensure that the exercise of public power is intra vires. ${ }^{54}$ Unlike the South African Constitution, which expressly recognises the rule of law, the rule of law "permeates ${ }^{55}$ the entire fabric" of the Indian Constitution. ${ }^{56}$ In ADM Jabalpur v S Shukla ${ }^{57}$ Kanna J held

"[the] rule of law is the antithesis of arbitrariness [...]. Rule of law is now the accepted norm of all civilized societies". ${ }^{5}$

By envisaging a rule of law (as opposed to a rule of men), the Indian Constitution conceptually and notionally recognises that nobody is above the law and the Constitution. ${ }^{59}$ This is not unlike the South African Constitution which recognises the supremacy of the Constitution and the rule of law. ${ }^{60}$ It is also clear that the rule of law is the basic rule of governance in India, which accords with the notion of the Indian Constitution being based on the concept of the rule of law. Every person, irrespective of their status in society or the executive, is subject to the supremacy of the rule of law. ${ }^{61}$ Moreover, in a system that is subject to the rule of law, unbridled power can never be countenanced; it is always subject to the constraints imposed by the rule of law. ${ }^{62}$ Authorities who are vested with wide discretionary powers such as the Prime Minister (chief of government and leader of the executive) and the courts are subject to the rule of law in as much as their decisions must be premised upon cogent legal principles that promote fairness, transparency, and equality. ${ }^{63}$

There can be no doubt as to the centripetal role played by the rule of law in Indian Constitutional law, in general, and administrative law, in particular. The genesis of the rule of law may have "mystical" connotations in light of its comity with ancient religious thought. However, with the influence of Dicey's theory on the rule of law, it has gained significant recognition as a trailblazer for how the judiciary can play a pivotal role in gauging whether the exercise of administrative and executive decisions are rational and conform to the tenets of the Constitutional values.

\footnotetext{
See ADM Jabalpur v S Shulka (1976) 2 SCC 521.

55 Jain and Jain Principles of Administrative Law (2015) 20.

56 Adopted by the Indian Constituent Assembly on 26 November 1949 and becoming effective 26 January 1050.

57 ADM Jabalpur v S Shulka supra 154.

58 Par 154.

59 Jain and Jain Principles of Administrative Law 21.

60 See ss 1 (c), 2 and 8(1)-(2).

61 See State of Punjab v Khanchand (1974) 2 SCR 768; VC Mohan v Union of India (1969) 2 SCC 262; Pancham Chand v State of HP (2008) SCC 123.

62 Maya Devi v Raj Kumari Batra (2010) 486; Mohinder Singh Gill v Chief Election Commissioner (1978) 1 SCC 405.

63 Maya Devi v Raj Kumari Batra supra; and Tyagi 201763 "The President of India: The Constitutional Head With Discretionary Powers" Indian Journal of Public Administration 330 337-340.
} 
The principle of legality, as discussed below, does not feature in Indian administrative law like in South African administrative law. The following section examines the rule of law in South African administrative law with particular focus on the significant role assumed by the principle of legality as an incident of the rule of law.

\section{THE PRINCIPLE OF LEGALITY IN SOUTH AFRICAN LAW}

A perusal of our law reports is replete with judgments ${ }^{64}$ in which our courts frequently employ the principle of legality in judicial review applications. Based on the reasons discussed below, the principle of legality should, strictly speaking, only be applied where the exercise of public power does not constitute administrative action in terms of the definition thereof under section 1 of the Promotion of Administrative Justice Act ${ }^{65}$ (PAJA). ${ }^{66}$

The principle of legality (expressed as an incident of the rule of law) was embraced with much acclaim by judges and legal academics. ${ }^{67}$ It serves as a means of holding accountable the exercise of all public power. ${ }^{68}$ It is sufficiently flexible to permit the review of public powers that do not constitute administrative action in terms of PAJA. ${ }^{69}$ It proves effective in animating the right to just administrative action expressed in section 33(1) of the Constitution until the latter is required to be given effect by national legislation such as PAJA. Elsewhere I explore the conceptual and restrictive difficulties encountered by employing PAJA for purposes of the judicial review of administrative action. Consequently, more reliance is placed on the principle of legality. ${ }^{70}$ However, the merit of employing the principle of legality in all instances (even where PAJA is applicable) is legally unsound in that it is contrary the principle of subsidiarity. Moreover, the discernible lack of consistency on the part of our courts in failing to apply PAJA (where same is applicable) and resorting to the principle of legality has also created uncertainty as to the basis upon which one can expect a matter will be judicially reviewed. ${ }^{71}$ Notwithstanding, the principle of legality provides an

64 In respect of administrative and non-administrative action.

653 of 2000

66 For further reading on why it is a legal prerequisite to bring a review application of administrative action first in terms of PAJA, and under the alternative the principle of legality, see Henrico "Subverting the Promotion of Administrative Justice Act in judicial review: the cause of much uncertainty in South African administrative law" 20182 Journal of South African Law 288 291-293.

67 Hoexter "The Principle of Legality in South African Administrative Law" 20044 Macquarie Law Journal 165 174ff.

68 Hoexter Administrative Law (2012) 122.

69 On account of falling within one of the exclusions listed in $\mathrm{s} 1$ (aa)-(ii) which exclusions fall outside the definition of administrative action as provided for in $s 1$ of PAJA. The aforesaid exclusions essentially concern themselves with powers or functions that are legislative, judicial or of an executive nature. See Burns and Henrico Administrative Law (2020) 208.

70 Henrico "Re-Visiting the Rule of Law and the Principle of Legality: Judicial Nuisance or Licence?" 20144 Journal of South African Law 742 753-754 and the authorities therein cited.

71 Henrico "Subverting PAJA in Judicial Review: The Cause of Much Uncertainty in South African Administrative Law" 20182 Journal of South African Law 288 296-304. See also Adonis v Minister of Public Works Western Cape [2020] ZAWCHC 87 (31 August 2020) 
abiding assurance that the exercise of all public (and even private) power is subject to judicial review in guaranteeing administrative justice and the realisation of transformative constitutionalism. ${ }^{72}$ In this sense, the principle of legality in South African administrative law is undeniably a positive phenomenon.

In the South African context, the principle of legality must be understood against the transformative constitutional project and culture of justification. Transformative adjudication on the part of our courts speaks to the former. Judicial review, in particular, speaks to the latter in terms of which there is a commitment to accountability, openness, and responsiveness. Because of the draconian measures imposed under the Apartheid regime and the extent to which judicial review was effectively marginalised and restricted in its operation, ${ }^{73}$ it comes as no surprise that our Constitution directly gives expression to the rule of law and its incident, the principle of legality.

The Constitutional Court adopts a teleological approach to interpret the Bill of Rights by taking into account foreign law. This is not a novelty as the Court is duty bound to do so. ${ }^{74}$ Axiomatic to our constitutional compact is the fact that the rule of law serves as a founding value of the South African democratic state. ${ }^{75}$ Drawing on the Canadian authority of The Matter of a Reference by the Government in Council Concerning Certain Questions Relating to the Secession of Quebec from Canada, ${ }^{76}$ the Supreme Court of Canada held:

"Simply put, the constitutionalism principle requires that all government action comply with the Constitution. The rule of law principle requires that all government action must comply with the law, including the Constitution. This Court has noted on several occasions that with the adoption of the Charter, the Canadian system of government was transformed to a significant extent from a system of Parliamentary supremacy to one of constitutional supremacy. The Constitution binds all governments, both federal and provincial, including the executive branch (Operation Dismantle Inc v The Queen [1985] 1 SCR 441455 ). They may not transgress its provisions: indeed, their sole claim to exercise lawful authority rests in the powers allocated to them under the Constitution and can come from no other source." 77

Gamble $J$ at par 213 correctly points out that the primary route to judicial review of administrative action is by using PAJA and using the principle of legality in instances where the exercise of public power does not constitute administrative action under PAJA. Such reasoning is consistent with the authority established by the Constitutional Court in Bato Star v Minister of Environmental Affairs 2004 (4) SA 490 (CC) 25 and confirmed in subsequent cases such as Minister of Health v New Clicks (Pty) Ltd 2006 (2) SA 311 (CC) 431, 433 and 586; and Minister of Defence and Military Veterans v Motau 2014 (5) SA 69 (CC) 29 and 30

72 Burns and Henrico Administrative Law 129-157.

73 See Madala "Rule under Apartheid and the Fledgling Democracy in Post-Apartheid South Africa: The Role of the Judiciary" 200126 North Carolina Journal of International Law and Commercial Regulation 743748 .

74 In terms of $s 39(1)(b)$ of the Constitution. Also see Currie and De Waal South African Constitutional Law in Context (2015) 31-32 and the authorities therein cited; Carmichele $v$ Minister of Safety \& Security 2001 (4) SA 938 (CC) 45-48.

$75 \mathrm{~S} 1(\mathrm{c})$

76 [1998] 2 SCR 217.

77 Secession of Quebec supra 72. Also see Reference Re Language Rights under the Manitoba Act, 1870 (1985) 19 DLR (4th) 124 where it was held: "Additional to the inclusion 
The above and article 20(3) of the Basic Law confirms the rechtstaatprinzip, which is related to the concept of the rule of law. ${ }^{78}$ The Constitutional Court in Fedsure Life Assurance Ltd $v$ Greater Johannesburg Transitional Metropolitan Council 79 introduced the principle of legality into South African administrative law. Chaskalson P observed:

\begin{abstract}
"It seems central to the conception of our constitutional order that the legislature and executive in every sphere are constrained by the principle that they may exercise no power and perform no function beyond that conferred upon them by law. At least in this sense, then, the principle of legality is implied within the terms of the interim Constitution. Whether the principle of the rule of law has greater content than the principle of legality is not necessary for us to decide here. We need merely hold that fundamental to the interim Constitution is a principle of legality." 80
\end{abstract}

According to the author's knowledge, there has since been no judgment ${ }^{81}$ that purports to answer the issue of whether the rule of law has greater content than the principle of legality. The terms "rule of law" and "principle of legality" are used by our courts interchangeably when dealing with the review of the exercise of public power. In Masethla $v$ President of the Republic of South Africa, ${ }^{82}$ the majority judgment held that the exercise of executive power is constrained by the principle of legality and specifically rationality. ${ }^{83}$ The minority (per Ngcobo J) held:

"The rule of law principle requires that the actions of all those who exercise public power must comply with the law, including the Constitution. It is central to the conception of our constitutional order that those who exercise public power including the President [...]." ${ }^{84}$

In Allpay Consolidated Investment (Pty) Ltd v CEO of SASSA, 85 Froneman J (for the majority) referred to vagueness and uncertainty as grounds for review under section 6(2)(1) of PAJA and emphasised how certainty in legislation and administrative law is central to the rule of law. ${ }^{86}$

of the rule of law in the preambles of the Constitution Acts of 1867 and 1982, the principle is clearly implicit in the very nature of a constitution. The Constitution, as the supreme law, must be understood as a purposive ordering of social relations providing a basis upon which an actual order of positive laws can be brought into existence. The founders of this nation must have intended, as one of the basic principles of nation building, that Canada be a society of legal order and normative structure: one governed by rule of law. While this is not set out in a specific provision, the principle of the rule of law is clearly a principle of our Constitution."

78 Article 20(3) provides that "[t]he legislature shall be bound by the constitutional order, the executive and the judiciary by law and justice."

79 Supra.

80 Fedsure supra 57 (own emphasis added).

81 By the Constitutional Court, Supreme Court of Appeal or any High Court.

822008 (1) BCLR 1 (CC), which had to do with the power of the President to remove the head of the NIA from office.

83 Masethla v President supra 78.

84 Masethla v President supra 173. See also Kruger "The South African Constitutional Court and the Rule of Law: The Masethla Judgment, A Cause for Concern" 201013 Potchefstroom Electronic Law Journal 468 473-474.

852014 (1) SA 604 (CC), which had to do with the setting aside of an unlawful tender.

86 Allpay supra 87. 
The Constitutional Court in Affordable Medicines Trust $v$ Minister of Health, 87 (per Ngcobo J for the majority) held:

\begin{abstract}
"The exercise of public power must therefore comply with the Constitution, which is the supreme law, and the doctrine of legality, which is part of that law. The doctrine of legality, which is an incident of the rule of law, is one of the constitutional controls through which the exercise of public power is regulated by the Constitution." 88
\end{abstract}

Although a bifurcated approach to the judicial review of administrative action is often adopted by our courts, it is clear that the principle of legality plays a pivotal role in South African administrative law $^{89}$ as illustrated by our courts. ${ }^{90}$

\title{
5 THE RULE OF LAW IN INDIA VERSUS THE PRINCIPLE OF LEGALITY IN SOUTH AFRICAN LAW
}

From the above discussion, it should be apparent that the rule of law, as employed in Indian administrative law, is as effective as the principle of legality in constraining the arbitrary and irrational exercise of all public power and in particular, the executive branch of government. The question arises: why do the approaches to the judicial review of the exercise of public power of the two judicial systems differ? Put differently, why has the rule of law been effective in Indian administrative law, while South African administrative law has distilled the principle of legality from the rule of law? To this, the author proposes an open-ended question followed by a submission. First, the debate concerning the rule of law has given rise to prismatic meanings and interpretations of the rule of law. ${ }^{91}$ In India, the

872006 (3) SA 247 (CC) which had to do with a constitutional challenge to certain aspects of a licensing scheme introduced by the government.

88 Affordable Medicines supra 49 [footnotes excluded].

89 See Hoexter 2004 Macquarie Law Journal 165ff; De Beer "A New Role for the Principle of Legality in Administrative Law: State Information Technology Agency Soc Ltd $v$ Gijima Holdings (Pty) Ltd" 2018135 SALJ $613614 \mathrm{ff}$.

90 Meaning that where PAJA is supposed to be relied upon as the national legislation giving effect to just administrative action under s 33(1) of the Constitution, instead the principle of legality is relied upon.

91 The "rule of" law as mentioned in s 165(3) of the Constitution must refer to, among other things, the doctrine of separation of powers; and ratio decidendi, whilst the rule of law as mentioned in $s$ (c) of the Constitution clearly has a more expansive meaning. For reading on the various meanings to be attributed to the rule of law, see Stein who refers to the "chameleon-like" character of the rule of law, Stein "Rule of Law: What Does It Mean?" 2009 18 Minnesota Journal of International Law 293 296; Gosalbo-Bono "The Significance of the Rule of Law and its Implications for the European Union and United States" 201072 University of Pittsburgh Law Review 229 231; Tamanaha "The History and Elements of the Rule of Law" 20121 Singapore Journal of Legal Studies 232 235; Waldron "The Concept of the Rule of Law" 20081 Georgia Law Review 1 10-12; Stephanopoulos and Ginsburg "The Concepts of Law" 201784 University of Chicago Law Review 147 153-158; Raz "The Rule of Law and its Virtue" in [this is the work of Raz, please see following: https://www.worldcat.org/title/authority-of-law-essays-on-law-and-mortality/oclc/749001172; and citation of work by Fox-Decent "Is The Rule of Law Really Indifferent to Human Rights?" 200827 Law and Philosophy 533-581 and the citation as appears on 533 at fn 1] The Authority of Law and its Virtue (1979) 210-232]; Fuller "The Morality that makes Law Possible" in The Morality of Law (1969) 146; Venter "South Africa: A Rechtstaat?" 201257 
Diceyean influence of the rule of law cannot be gainsaid; neither can the ancient spiritual philosophies be ignored. Is it on account of these two aspects that the rule of law in and of itself has proved adequate? Secondly, as mentioned above, South Africa's socio-political past is rooted in an authoritative culture where government actions and the exercise of public power previously took place in the context of our courts having limited powers of review. In this a sense, something more than the mere rule of law is required. Hence, the principle of legality, as an incident of the rule of law, is a guarantee in our constitutional democracy that the exercise of all public power is subject to judicial review. This underscores the constitutional imperatives of accountability, responsiveness, and transparency.

\section{CONCLUSION}

It would appear that the rule of law is as effective as the principle of legality in holding to account the exercise of discretionary powers in administrative law. Whilst not expressly mentioned in the Indian Constitution, the rule of law is a bastion upon which the interpretation of the Constitution rests and is referred to for purposes of giving effect thereto. South African administrative law deemed it necessary to distil the principle of legality from the rule of law. In terms of both Indian and South African administrative law, the exercise of discretionary powers or public powers may be set aside on judicial review if it is exercised in a manner that is contrary to the provisions of the respective constitutions. An additional common feature between the two countries is that, at the very minimum, the rule of law operates to constrain the exercise of arbitrary or irrational power. In South African administrative law, any exercise of power that impugns the rule of law, in general, or the principle of legality, in particular, may be set aside on judicial review. In comparison to Indian administrative law, it may thus be argued that the rule of law is a general ground upon which judicial review may take place. On the other hand, in South African administrative law, the principle of legality (as an incident of the rule of law) is a more specific ground upon which judicial review takes place.

McGill Law Review 721 741; Mathews State, Security and the Rule of Law (1986) 16; De Ville "The Rule of Law and Judicial Review: Re-Reading Dicey: The Constitutional Context" 20061 Acta Juridica 62 65-68; and Dworkin Freedom's Law: The Moral Reading of the American Constitution (1997) 82-83. Also see S v Mabena 2007 (1) SACR 482 (SCA) 2. 